\title{
Moderating Effects of Self-efficacy on Chinese Language Achievement for Minority Students
}

\author{
Qiuling Zhang \\ Beijing Normal University, Beijing, China \\ Ningning Zhao* \\ Beijing Normal University, Beijing, China \\ Xiangying Han \\ Beijing Normal University, Beijing, China \\ Li Cheng \\ Beijing Normal University, Beijing, China \\ Yufei Zheng \\ Shan Xi University, Taiyuan, China
}

\begin{abstract}
The purpose of this article was to explore the effect of the contextual variables and individual variables on the language achievement for the minority students in Chinese primary school. There were 9,102 students from grade 2 to grade 6 who participated in the investigation, including 578 minority and 4731 girls from five regions with different developing levels. Firstly, the results show that the ethnicity does not have a direct effect on the language achievement and the self-efficacy has moderating effect for ethnicity on language achievement. Secondly, the gender and parents' career have a direct and indirect effect on the language achievement. Male minority students with lower parents' careers level would have a high probability to fall in the language achievement. But, all these effects are moderated by the students' self-efficacy. Finally, it implied that the early efforts to promote the students' self-efficacy beliefs would enhance the future language achievement for the minority students in the primary school.
\end{abstract}

Index Terms—-self-efficacy, parents' career, language achievement, minority

\section{INTRODUCTION}

Minority students are the disadvantaged group in one country who might face the problem of the language. The different language would affect their communication with the major groups. The situation is the same in China. Bilingual education policy is one of the important policies for the minority students in China. After Year 1949, Chinese government set up a set of policies minority groups. There were officially recognized 56 "nationalities" (ethnic groups) in contemporary mainland China, including the Han majority and 55 minority groups. There were 55 minority groups in China who used more than 80 ethnic languages belonging to Sino-Tibetan, Indoeuropen, Altaic, South Asian and South Island. And in Year 2019, minority occupied $8.5 \%$ population in China. Thus, the bilingual education was a good choice for the minority people to develop and merge into the mainstream life.

In order to support for these ethnics students, Chinese government carried out two sets of policies for the students. In the one hand, government guaranteed the legislation of the right of minority language in China in all versions of the Constitutions (Zhou, 2000).In the autonomous area of different ethnic minorities, the minorities group can use and develop their own languages as official working language in administration, election, courts, broadcasting, publication and schools (Ma, 1981). In the other hand, Chinese government provided education on national common spoken language (Mandarin Chinese) as to create an environment of equal intercourse with other ethnics from Year 1956 (Central Committee and the State Council, CPC, 1956). So, there was a parallel school system for minority: one is ordinary mainstream school system using the Mandarin as teaching language while teaching English as second language; another is ethnic school system, using the local minority language as the medium of instruction and Mandarin as a second language (National People's Congress, NPC, 1995). In this paper, Chinese language education refers to the official language education in first school system. In 2004, The Ministry of Education issued "Interim measures for the examination and approval of textbooks for ethnic minorities in Primary and Middle Schools", in order to ensure the quality of teaching materials for ethnic minorities and promote the construction of teaching materials (MOE, 2004).

\footnotetext{
* Correspondent author: Ningning Zhao, Department of Chinese language Education, School of Chinese language and literature education, Beijing Normal University-Beijing 100875, P.R. China. Email: tintinning@gmail.com
} 
From 2017, the Chinese government stipulated that students in compulsory education would use unified Chinese teaching materials, including ethnic minority areas. Starting from 2019, unified Chinese teaching materials will also be gradually used in senior high schools. National coverage is expected to be achieved by 2022 . The minority students should have to take the same Chinese language education in order to make students in ethnic minority areas enjoy fair and quality education, and improve the spoken and written language level of minority students in mandarin (MOE, 2017).

In China, Chinese language education was an important language course. Minority students also have to take the language courses of Mandarin Chinese during the primary schooling in order to merge in the mainstream life. Disadvantaged students who are low SES, minority and girls have drawn greater attention in China in recent years. It is necessary to check for the language achievement result for the minority students. But, there were limited studies on the Mandarin Chinese achievement considering the ethnicity. Thus, the purpose of the present paper aims to describe further explore the linkage in the elementary schools:

(1) Which kinds of the variables contributing to the language achievement for students, especially for the minority students? Do different ethnicity, parents' career and gender affect the language achievement?

(2) Do social and emotional beliefs (self-efficacy) enable children to succeed in the language learning?

\section{THEORETICAL BACKGROUND}

\section{A. Effect of Ethnicity, Gender, Parents' Career, And Self-efficacy on Language Achievement}

Minority student was supported to learn Mandarin Chinese. But, there are a lot of pressures for the minority schools and mainstream schools, including the diverse student backgrounds.

Gender. In most countries, girls were expected to perform better than boys in the language learning (Marks, 2008). One explanation for gender gaps in student performance is the gender difference in students' educational and occupational expectations (Teachman \& Paasch, 1998). Another explanation is school system and social system's equality (Marks, 2008). Recently, some studies revealed that girls do perform better than boys in language subjects, probably because of teachers' stereotype that language is considered to be a somewhat feminine subject (Achtziger, Bayer, 2020). Girls were rated more enthusiastic and more gifted than boys (McLellan, Forbes \& Li, 2021). Some studies further explained that stereotypes lead to significant variance in self-concept among girls and boys, resulting in differences in language performance (Espinoza, Strasser, 2020).

Ethnicity. The ethnicity was an important factor for the language learning. Studies reveal that in American, the gap on the language achievement between the minority students and mainstream students grows larger as the children progress through school (Garcia \& Zimmerman, 1972). Black first-graders scored lower in language and literacy than students of other ethnicities, which indicates that teachers' ratings are influenced by their more negative perceptions on academic behavior of black students (Irizarry, Cohen, 2019). But few studies were done in China. Recently, a study in Hong Kong revealed that the early support from immersion courses may help ethnic minority students to achieve higher achievements in Chinese (Li, Li \& Hua, 2020).

SES. Students from low SES family were expected to attain the lower achievement in language compared to their peers from high SES family (Marvin \& Mirenda, 1993). The reason might be referred to the parents from lower SES who were busy and lack of the early care to their children (Anderson-Yockel, \& Haynes, 1994; Marvin \& Mirenda, 1993).Some studies revealed that the performance of low-SES children in Chinese word reading and dictation is not as good as that of middle-SES children (Fung, Chung, 2020). One possible explanation is that low-SES parents less able to provide adequate linguistic mediation, literacy instruction for their children (Cabell, Justice, Logan \& Konold, 2013).

Self-efficacy. But, more and more researches show individual emotional competencies moderated the students' family background and academic achievement (Raver \& Knitzer, 2002). Evidences on effect of socioemotional skills on the students' academic success were emerged which implies that the teachers should emphasize the development of the socioemotional skills during the courses (Raver \& Knitzer, 2002). Results supported that academic self-efficacy beliefs were positively correlated with reading achievement. Self-efficacy may impact student's achievement scores by subject (Louis \& Mistele, 2012). It was believed that early efforts to promote children's self-regulatory skills would enhance future academic self-beliefs and achievement, particularly in literacy (Liew, McTigue, Barrois, Hughes, 2008). Selfefficacy seems to be an important variable for writing also. Students' confidence in their writing capabilities influences their writing motivation as well as various writing outcomes in school (Pajares, 2003). In an Asian Confucian cultural context, self-efficacy is strongly related to self-regulated learning writing strategies and students' confidence in completing tasks, which can explain why self-efficacy can improve writing skills (Bai, Wang \& Nie, 2021).

\section{B. Effect of Ethnicity, Gender and Parents' Career, on Self-efficacy}

Self-efficacy was defined as "people's judgments of their capabilities to organize and execute courses of action required to attain designated types of performances" (Bandura, 1997, p. 391). Self-efficacy was affected by a lot of variables.

Gender. The previous study showed that the effect size between boys and girls in self-efficacy for reading was 19 . Girls have higher self-efficacy than boys (Smith, Smith, Gilmore and Jameson, 2012). But compared to the effect size of gender on reading achievement, the effect of self-efficacy was rather small (Smith, Smith, Gilmore and Jameson, 
2012). Girls were considered to have higher levels of writing self-efficacy beliefs (Pajares \& Valiante, 2001), and selfefficacy beliefs in learning French is higher than boys (Mills, Pajares \& Herron, 2007). However, there is not much difference in self-efficacy between boys and girls among English learners, which may indicates that the gender differences in self-efficacy vary in different language and cultures (Iwaniec, 2019).

Ethnicity. Gender differences in role attitudes and their impact on self-efficacy is moderated by culture (Buchanan, \& Selmon, 2008). The research results showed that self-efficacy was impacted by the cultural variables (Oettingen, 1995). It was reviewed that moderate group differences were found on the self-efficacy (Johnson, Kim, Johnson-Pynn \& Schulenberg, 2012).A study reveled that African American and Caucasian students had more academic self-efficacy than Asian American students at the beginning of semester. But the ethnic differences are no longer obvious at the end of the semester (D'Lima, Winsler \& Kitsantas, 2014).

SES. SES had an important effect on general self-efficacy and well-being (Tong \& Song, 2004). The parents' achievement in the workplace contributed to children's self-efficacy. The research results reviewed that low SES students scored significantly lower than their peers on general self-efficacy and subjective well-being (Tong, \& Song, 2004).

To summarize, the literature on ethnicity, gender, parents' career and self-efficacy beliefs in relationship to reading clearly suggests that they are strong and potentially instructionally relevant variables on language achievement (See Figure 1).

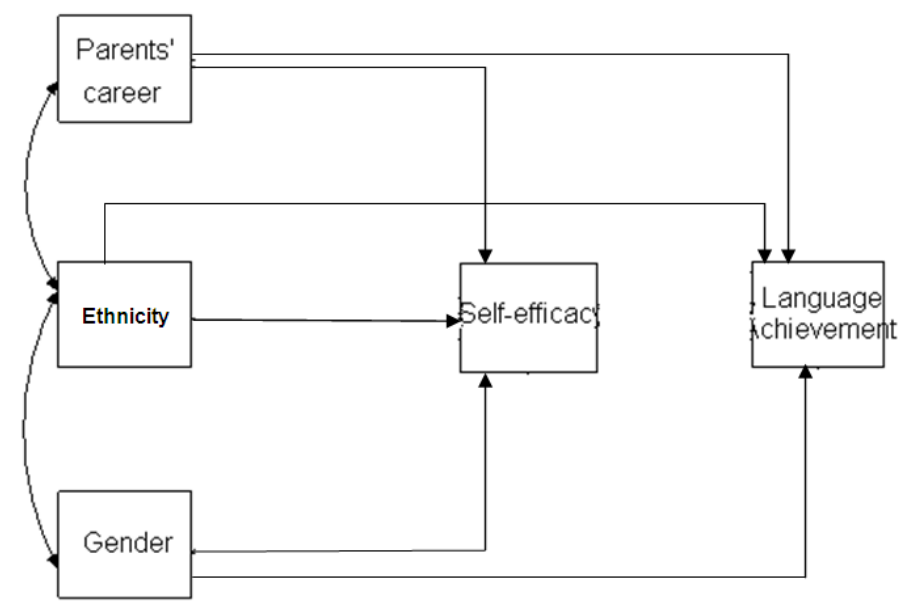

Figure 1. Hypothesis of the model

\section{METHODOLOGY}

\section{A. Samples}

Multi-stages stratified method was used to select the samples considering about the economic development levels, rural/urban. A total of 9,102 students and their parents participated from grade 2 to grade 6 in 20 primary schools of five regions with different economic development level. There were 578 minority students and 4731 girls. The background of the students on gender, ethnicity and parents' career were gathered which was supported by the teachers and parents.

TABLE I.

SAMPLES DESCRIPTIVE $(\mathrm{N})$

\begin{tabular}{c|c|c|c|c}
\hline Grade & Gender & Majority & Minority & Total \\
\hline Grade 2 & Boys & 813 & 70 & 883 \\
\hline & Girls & 907 & 65 & 972 \\
\hline Grade 3 & Boys & 800 & 72 & 872 \\
\hline & Girls & 863 & 70 & 933 \\
\hline Grade 4 & Boys & 784 & 70 & 854 \\
\hline & Girls & 916 & 61 & 977 \\
\hline Grade 5 & Boys & 788 & 57 & 845 \\
\hline & Girls & 848 & 58 & 906 \\
\hline Grade 6 & Boys & 883 & 34 & 917 \\
\hline & Girls & 922 & 21 & 943 \\
\hline Total & & 578 & 8524 & 9102 \\
\hline
\end{tabular}

\section{B. Measures}

Chinese achievement 
In China, objectives of the course of Chinese were to improve the reading, writing and speaking which were two of the "3 R's of school" (Freeman \& Hatch, 1989). The measurement of the Chinese includes vocabulary, grammar, reading comprehension and writing in the area. The students' Chinese language achievement in the Mid-term examination were collected from the teachers and standardized in the school in order to avoid the biases between schools.

\section{Family Contextual Variables}

Family contextual variables include parents' career and ethnicity.

Ethnicity: Minority people was coded 1.

Parents Career: Father and mother's job level (ranging from 1=highest to 27 lowest). The Exploratory factor analysis (EFA) by SPSS on the father and mother' job level reveals to be one factor for Parent's Career. Satisfactory goodness-of-fit indexes are observed $\left(x^{2}=265.80, d f=8, p<.00, C F I=.98, T L I=.96, R M S E A=.048\right)$ by the confirmatory factory analysis (CFA).

\section{Individual Variables}

Gender: Boys was coded 1.

Self-efficacy: A 5-point Likert Self-efficacy scale (MSC) by Marat (2005) was revised into scale on language and used to estimate the students' self-efficacy. There were seven sub-scales including self-beliefs on motivation, cognitive strategies, resource management, self-regulation learning, leisure time skills, self-assertiveness and meeting others expectation. For example, the item asks "How well do you believe you can set goals for yourself to direct your activities?"Not Well at all (coded 1) to very well (coded 5). Cronbach's alpha reliability of the final version was .97 which reflected high goodness-of-fit indices.

\section{E. Data Analysis}

Firstly, the correlation analysis was used to test the associations between the different variables. Secondly, structural equation model (AMOS 7.0) was used to test the complex relationships between the variables and the language performance. The indices of the comparative fit index (CFI), the goodness-of-fit index (GFI), the adjusted goodness-offit index (AGFI), the Tucker-Lewis index (TLI), and the root mean square error of approximation (RMSEA) were used to present the model of goodness-of-fit (Hu \& Bentler, 1999).

\section{RESULTS}

\section{A. Descriptive Results}

The correlation was carried out to present the relationships between the variables (See Table 2). The results suggest positive and significant interrelationships between language performance and other individual variables. Also, significant correlations can be observed between the different variables. None of the correlation values reflect problematic collinearity.

The results suggest a strong interrelation between language achievement and the individual variables. Language achievement is strongly correlated with Gender $(\mathrm{r}=-.091, \mathrm{p}<.01)$. Other important correlations are found between parents' career and language achievement $(r=.015, .01<\mathrm{p}<.05)$, between self-efficacy and language achievement $(\mathrm{r}$ $=.09, \mathrm{p}<.01)$. In addition, self-efficacy was strongly correlated with gender $(\mathrm{r}=-.079, \mathrm{p}<.01)$, ethnicity $(\mathrm{r}=-.058, \mathrm{p}$ $<.01)$ and parents' career $(\mathrm{r}=.068, \mathrm{p}<.01)$.

TABLE II.

CORRELATIONS BETWEen VARIABLES AND LANGUAGE ACHIEVEMENT

\begin{tabular}{c|c|c|c|c}
\hline & Ethnicity & $\begin{array}{c}\text { Parents' } \\
\text { Career }\end{array}$ & Self-efficacy & $\begin{array}{c}\text { Language } \\
\text { Achievement }\end{array}$ \\
\hline Gender & $-.023^{*}$ & -.013 & $-.079 * *$ & $-.091 * *$ \\
\hline Ethnicity & & $-.130 * *$ & $-.058^{* *}$ & .003 \\
\hline $\begin{array}{c}\text { Parents' } \\
\text { Career }\end{array}$ & & & $.068 * *$ & $.015^{*}$ \\
\hline \multicolumn{2}{c|}{ Self-efficacy } & & & $.090 * *$ \\
\hline \multicolumn{2}{l}{ Note: $* *: \mathrm{p}<.01 ; *: \mathrm{p}<.05}$.
\end{tabular}

\section{B. Structure Equation Models}

Structure equation model was applied to test the hypothesis between the individual variables and the language performance. As we can check in the Table 2, there was no significant correlation between ethnicity and language achievement. Thus, in order to pursue for the parsimony model to explain the language achievement without losing the predictive power, we tried to delete the direct effect from ethnicity to language achievement and compared for the model A and model B (See Table 3). The deviance of model A and model B was $1.754(\mathrm{df}=1, \mathrm{p}>.05)$ which means when the direct effect of ethnicity on language achievement could be removed from model A without any impacts. All 
the goodness-of-fit indices for model B are in line with recommended benchmarks for acceptable fit: chi-square $=4.93$ $(\mathrm{df}=2 ; \mathrm{p}=.086>.05), \mathrm{GFI}=1.000, \mathrm{AGFI}=.998, \mathrm{NFI}=.993, \mathrm{RMSEA}=.031$. The total proportion of explained variance in prospective computer use amounts to $3 \%\left(\mathrm{R}^{2}=.03\right)$.

TABLE III.

MODEL SELECTION

\begin{tabular}{c|c|c}
\hline & Language & Achievement \\
\cline { 2 - 3 } & Model A & Model B \\
\hline Gender & $-.09^{* *}$ & $-.09^{* *}$ \\
\hline Ethnicity & .01 & - \\
\hline Parents' Career & $.03^{*}$ & $.03^{*}$ \\
\hline Self-efficacy & $.15^{* *}$ & $.15^{* *}$ \\
\hline Adjusted $R^{2}$ & .03 & .03 \\
\hline$x^{2}$ & 3.176 & 4.93 \\
\hline df (p-value) & $1(.075)$ & $2(.086)$ \\
\hline$\triangle x^{2}$ & & 1.754 \\
\hline$\triangle$ df & & 1 \\
\hline GFI & 1.000 & 1.000 \\
\hline AGFI & .998 & .998 \\
\hline NFI & .995 & .993 \\
\hline RMSEA & .015 & .031 \\
\hline AIC & 31.176 & 30.930 \\
\hline
\end{tabular}

Note. - not included in model, n.s. not

significant: $* \mathrm{p}<.05, * *_{\mathrm{p}}<.01$

Figure 2 shows the resulting path coefficients in the model B. Only significant effects have been retained in the model. There were correlations between the predictor variable of ethnicity and parents' career $(r=-.13, p<.01)$, between ethnicity and gender $(\mathrm{r}=-.03, \mathrm{p}<.01)$.

The direct and indirect effects of the predictor variables on the endogenous variables were calculated as standardized beta-weight (path coefficients or $\beta$ 's). Language achievement was directly predicted by gender $(\beta=-.09, \mathrm{p}<.01)$, parents' careers $(\beta=.03, .01<\mathrm{p}<.05)$ and self-efficacy $(\beta=.15, \mathrm{p}<.01)$. Girls outperform boys in language achievement. The student whose parents have higher level job gets good achievement in language learning than the students whose parents have lower level job. Students with higher self-efficacy achieved higher in the language achievement. These results seem to be line with the previous studies (Louis, \& Mistele, 2012; Marks, 2008; Marvin \& Mirenda, 1993).

All relationships between these exogenous variables and language achievement were indirect relationships, considering the role played by the mediating variables: self-efficacy. The mediating role of the self-efficacy was presented when we consider the path from ethnicity $(\beta=-.07, \mathrm{p}<.001)$ via self-efficacy to language achievement. In a comparable weaker way, gender $(\beta=.08, \mathrm{p}<.001)$ and parents' career $(\beta=.10, \mathrm{p}<.001)$ had an indirect effect on language achievement mediating by self-efficacy $(\beta=.09, \mathrm{p}<.01)$.

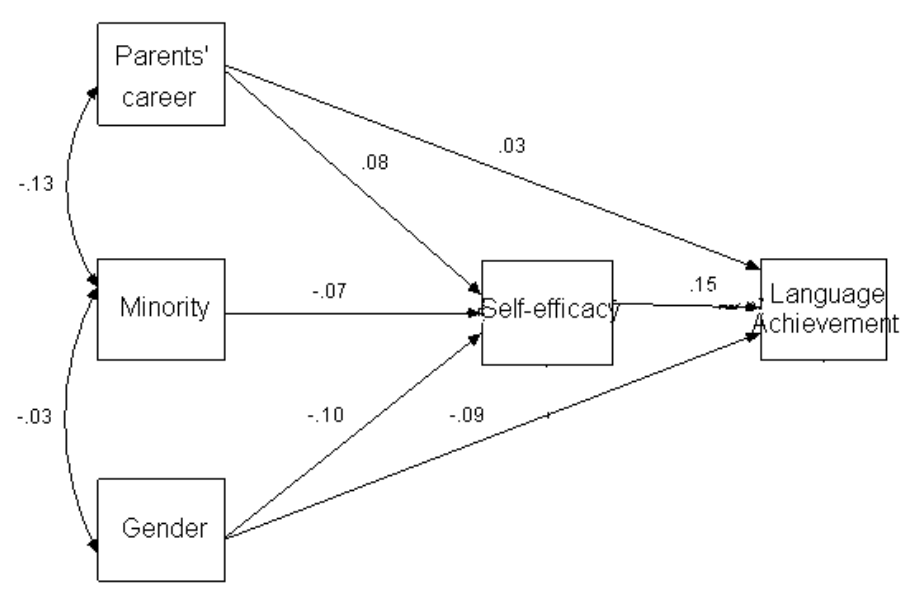

Figure 2. Path of the variables on the language achievement. 


\section{DisCUSSION AND IMPLICATION}

The vital research question in this article focused on the minority student and aimed to explore the demographic variables (such as gender) and the SES variables which might explain for the students' language achievement. There were two important results which might raise our attention: firstly, the minority student achieved the same language performance as majority students in the mainstream schools; secondly, the difference of the language performance was moderated by the students' self-efficacy in the schools.

\section{A. The Minority Students Have the Same Achievement in Language Achievement}

The results of this study confirmed that at the student level, there were many factors influencing language achievement. In the present study, gender, parents' career and students' self-efficacy were largely confirmed except for the ethnicity. The ethnicity of the students did not have direct impact on the language achievement. The result was not the same as the previous studies in the other countries (Garcia, \& Zimmerman, 1972). Although there was correlation between the ethnicity of the students and the parents' career of the students, the gap of language achievement between the majority and minority students was filled by the schools in developing countries.

This situation could be related to the education policy in China. Firstly, although the minority student lived in the minority area, the Chinese language replaced minority language as the official one. Thus, the change of the official language caused more and more minority families started to speak Chinese at home. Chinese was a whole group integrated by lots of peoples. After Year 1949, thousands of Han people migrated to the minority area. And there were four types of language education approaches: the first one is for the minority persons who live alone and communicate by their own language, for example, Tibetan, Mongolian, Uygur, Kazak(MOE, 1956). For these students, the Chinese language was the second language for the minority students. The second one is for the minority persons who live with Han people and have few communications with Han people in the same Provinces (MOE, 1953). The minority persons adopted their own living habits and language. Their children speak the minority language from birth and taught by their own language during Grade 1 and Grade 3. After Grade 3, the Chinese language should be added as a course and students have to adapt to the two languages. The third one is for the minority persons who live with Han people and there was no difference between the living styles. In this study, the samples were selected from the third one. From Year 1982, the syllabus for the Chinese language for minority students was set up which implied that the standard of the language education started (MOE, 1982). The forth one is for the special students who can participate in the class (call "minzuban", means minority class) in the schools where are in the developed provinces. These minority students are selected from the minority area and enjoy the free education (MOE, 1980). In 2000, The Law of National Language and Writing System of Wider Communication was promulgated, advocating bilingual education (standard Mandarin and minority languages) for ethnic minorities. As a result, the mixed schools of Han and ethnic minorities in minority areas had gradually replaced the separate schools. And the national common language had become the main teaching language in bilingual education. At the same time, the bilingual classes in preschool were widely popularized (Standing Committee of NPC, 2000). In 2017, the Chinese government proposed to carry out bilingual education scientifically and steadily. It's essential unswervingly carry out national common language education, while protecting minority languages (NEAC, 2017). The minority students should have to take the same Chinese language education (MOE, 2017).

Secondly, in our study, all of the schools were from the mainstream schools. Since Year 1953, the Chinese government agreed to set up the mainstream schools if the minority area could not teach in the school by their own language (Ministry of Education, MOE, 1953; p.195). The minority students enrolled in the mainstream schools and were taught by the Chinese language. And the study confirmed whether majority and minority student could achieve the same performance in the Chinese language. Then, the minority student enrolled in the mainstream schools could have the same opportunity as the majority students in the same school. This was an effort of the Chinese government to improve the educational equity. Also, for the minority students who enrolled in the minority schools, there were some special education policies to enhance their opportunity in the further schooling. For example, in Year 1962, Ministry of Education (MOE, 1962, p.1114) launched an education policy of "Announcement on the priority of the minority students to enroll in the high school". The policy allowed that, when the minority students and majority students had the same score, the minority students had the priority to enroll in the high school. And, minority students were exempt from the examination related to Chinese language. In 2004, the Chinese government had issued a Training Program for Highlevel Professionals of Ethnic Minority Origins, which enrolled master's and doctoral students from ethnic minorities in a number of key universities. Students enjoined a special preferential score policy, and tuition fees are borne by the government (MOE, 2005).

\section{B. Students' Self-efficacy Moderated the Effect of the Family Contextual Variables}

Our findings underpin the direct and indirect relationship between students' variables and student language achievement (See Figure 2). Although the minority was not the variables which affected the language achievement directly, the variable of students' self-efficacy moderated the effect of the students' demographic variables and the SES variables on the language achievement which was in line with the previous studies (Liew, McTigue, Barrois, Hughes, 2008; Louis \& Mistele, 2012). Thus, it implied that early efforts to promote children's social and emotional learning 
positively influence their concurrent and future academic success (e.g., Rimm-Kaufman, Fan, Chiu, \& You, 2007; Zins, Bloodworth, Weissberg, \& Walberg, 2004).

The traditional emphasis in schools has been on academic instruction alone. In the past few decades, there have been growing efforts toward a more holistic approach. The emotional development was assumed to be related with academic achievement (Caprara, Bararanelli, Pastorelli, Bandura, \& Zimbardo, 2000; Elias, Zins, Weissberg, Frey, Greenberg, Haynes, et al., 1997). Some studies have revealed that the growth in the reading ability is related to the growth in selfefficacy (Caprara et al., 2008).Thus, the disadvantaged students who were female minority with lower parents' career could be supported by the emotional development in the schools. The effective project of the emotional development, such as the project on the students' self-efficacy, could improve the disadvantaged students' academic achievement. The self-efficacy in the school could make up for the students' disadvantaged background in the primary school, as we can see from the Figure 2. Thus, in the future, more training projects should be done for the teacher to pay attention for the students' emotional development and the academic development at the same time, such as Social and Emotional Learning (SEL) programs (Durlak, Weissberg, Dymnicki, Taylor, \& Schellinger, 2011). Improving self-efficacy may help narrow the gap of language achievement (Caprara et al., 2008). Further studies revealed that more vulnerable students rarely increase self-efficacy during the middle school years, indicating that this period may a crucial time for teachers to emphasize and develop positive academic self-concept (Soland \& Sandilos, 2021). Real emotional development is most likely to occur in an encouraged learning environment (Sakiz, Pape, \& Hoy, 2012).

Under the holistic model, Chinese equal people relationship contributed to the students' language achievement in China. The equal people relationship was set up in the educational policy. The minority students were respected equally as the Han students. All of the students in the class were respected equally. No discrimination was allowed in the class. Even more, the government set up some policy which benefited for the minority students, for example, the priority entrance for the university policy in the minority area (MOE, 1962), the extra opportunity for the minority students to immerse in the language learning, and the support from the teacher and their peers. The Chinese government not only emphasized the equality of all ethnic groups and the construction of a national community, but also paid attention to the all-round development of students. In 2017, the report of the 19th CPC National Congress pointed out that it is necessary to implement the fundamental task of Moral Education and People Cultivation, developing socialist successors with all-round development of morality, intelligence, physique, beauty and labor (CPC National Congress, 2017). Moral Education and People Cultivation means that education should achieve people's all-round development, rather than just emphasizing intellectual education. The ultimate goal of education is to realize people's own happiness, free and all-round development.

\section{CONCLUSION AND LIMITATION}

The studies explored the effects of the environmental variables and individual variables on the Chinese language achievement. The results from this study are generally supportive of what has been found in the research literature, but provide additional information. For the ethnicity, it was showed that the minority students were at risk of the language achievement which might affect the students' opportunity in the further schooling. The ethnicity does not affect the language achievement directly but through the self-efficacy. In china, the minority students and Han people students were respected as Han people students in education. All of the students at the same class were regarded as equality. On the contrary, the minority students would have more advantaged policies in language education.

However, there are some limitations which should be improved for the further studies.

First, though a large sample from 20 schools in five provinces in China, the sample was still small to reflect the Chinese population. Secondly, the individual variables were the only variables which predicted the language achievement (van Braak et al., 2004). School level factors (leadership, school culture, teacher variables etc.) and province level factors may also influence the students' language achievement. In the future studies, there would be more variables involved in the model. And a multilevel analysis would be helpful to integrate the above levels. Thirdly, the adoption of a longitudinal approach could be recommended to track changes in language achievement considering the students' ethnicity. Lastly, the sample in this study was selected from the mainstream school in the minority area. In the further studies, students from the minority school will be explored.

Despite these limitations, the current study contributes to the literature about minority and language achievement in a number of ways. Firstly, form a theoretical perspective, more insight has been obtained in the complex interplay of students' demographic variables, individual emotional variables and language achievement. Second, emotional processes affect how and what we learn, schools and families must effectively address these aspects of the educational process for the benefit of all students. Minority was not the predictor for the language achievement while the students' self-efficacy moderated the effect of the ethnicity. Thus, the teachers and the schools should be involved in the students' emotion development. Especially, the essential role of students' self-efficacy should be paid more attention in the minority area. Thirdly, the equality of the minority students in language achievement can support for the students further development. And these related minority education policy could be recommended to the other countries. For example the differentiation of the education policy for different kinds of the minority students. 


\section{ACKNOWLEDGMENTS}

This research was supported by the Project of the National Social Sciences Program Fund, China (The factors which contributing to the immigrated students in China, No. 13CSH072).

\section{REFERENCES}

[1] Anderson-Yockel, J., \& Haynes, W. (1994). Joint book-reading strategies in working-class African American and White mother-toddler dyads. Journal of Speech and Hearing Research, 37, 583-593.

[2] Achtziger, A., Bayer, U.C. (2020). Self-control mediates the link between gender and academic achievement in sex-stereotyped school subjects in elementary and in higher secondary schools. Current Psychology, 39, 1683-1695.

[3] Bandura, A. (1997). Self-efficacy: The exercise of control. New York: W.H. Freeman and Company.

[4] Bai, B., Wang, J., \& Nie, Y. (2021). Self-efficacy, task values and growth mindset: what has the most predictive power for primary school students' self-regulated learning in English writing and writing competence in an Asian Confucian cultural context?. Cambridge Journal of Education, 51(1), 65-84.

[5] Buchanan, T. \& Selmon, N. (2008). Race and gender differences in self-efficacy: Assessing the role of gender role attitudes and family background. Sex Roles, 58(11-12), 822-836.

[6] Cabell, S. Q., Justice, L. M., Logan, J. R., \& Konold, T. R. (2013). Emergent literacy profiles among prekindergarten children from low-SES backgrounds: Longitudinal considerations. Early Childhood Research Quarterly, 28(3), 608-620.

[7] Caprara, G.V., Barbaranelli, C., Pastorelli, C., Bandura, A., \& Zimbardo, P.G. (2000). Pro-social foundations of children's academic achievement. Psychological Science, 11, 302-306.

[8] Caprara, G. V., Fida, R., Vecchione, M., Del Bove, G., Vecchio, G. M., Barbaranelli, C., et al. (2008). Longitudinal analysis of the role of perceived self-efficacy for self-regulated learning in academic continuance and achievement. Journal of Educational Psychology, 100(3), 525-534.

[9] Central Committee and the State Council (CPC). (1956). The recommendation for Mandarin Chinese popularization. In He, D. (ed.), Important Education Document From Year 1949-1975 in P.R. China. Haikou: Hainan publisher, 572-573.

[10] CPC National Congress. (2017). Report on the 19th National Congress of the Communist Party of China. http://www.12371.cn/2017/10/27/ARTI1509103656574313.shtml (accessed 03/2/2021).

[11] D'Lima, G. M., Winsler, A., \& Kitsantas, A. (2014). Ethnic and Gender Differences in First-Year College Students' Goal Orientation, Self-Efficacy, and Extrinsic and Intrinsic Motivation. The Journal of Educational Research, 107(5), 341-356.

[12] Duncan, G. J., Dowsett, C. J., Claessens, A., Magnuson, K., Huston, A.C., Klevanov, P, et al. (2007). School readiness and later achievement. Development Psychology, 43(6), 1428-1446.

[13] Durlak, J. A., Weissberg, R. P., Dymnicki, A. B., Taylor, R. D., \& Schellinger, K. (2011). The impact of enhancing students social and emotional learning: A meta-analysis of school-based universal interventions. Child Development. 82(1), $405-432$.

[14] Elias, M. J., Zins, J. E., Weissberg, R. P., Frey, K. S., Greenberg, M. T., Haynes, N. M., et al. (1997). Promoting social and emotional learning: Guidelines for educators. Alexandria, VA: Association for Supervision and Curriculum Development.

[15] Espinoza, A.M., Strasser, K. (2020). Is reading a feminine domain? The role of gender identity and stereotypes in reading motivation in Chile. Social Psychology of Education, 23(4), 861-890.

[16] Fung, Wk., Chung, K.K. (2020). The role of socioeconomic status in Chinese word reading and writing among Chinese kindergarten children. Reading and Writing, 33, 377-397

[17] Garcia, A. B., \& Zimmerman, B. J. (1972). The effect of examiner ethnicity and language on the performance of Bilingual Mexican-American First grade. The Journal of Social Psychology, 87, 5-11.

[18] Hu, L., \& Bentler, P. M. (1999). Cutoff criteria for fit indexes in covariance structure analysis: Conventional criteria versus new alternatives. Structural Equation Modeling, 6, 1-55.

[19] Irizarry, Y., Cohen, E.D. (2019). Of Promise and Penalties: How Student Racial-Cultural Markers Shape Teacher Perceptions. Race and Social Problems, 11(2), 93-111.

[20] Iwaniec, J. (2019). Language learning motivation and gender: The case of Poland. International Journal of Applied Linguistics, 29(1), 130-143.

[21] Johnson, L. R., Kim, E.H., Johnson-Pynn, J.S. \& Schulenberg, S.E. (2012). African and U.S. Youth ethnic identity, selfefficacy, and intercultural attitudes in east. Journal of Adolescent Research, 27(2), 256-289.

[22] Liew, J., McTigue, E.M., Barrois, L., \& Hughes, J. (2008). Adaptive and effortful control and academic self-efficacy beliefs on achievement: A longitudinal study of 1st through 3rd graders. Early Child Research Quarterly, 23(4), 515-526.

[23] Louis, R. A. \& Mistele, J. M. (2012). The differences in scores and self-efficacy by student gender in mathematics and science. International journal of science and mathematical education, 10, 1163-1190.

[24] Ma Yin. (1981). China's Minorities. Beijing: People's Press.

[25] Marat, D. (2005). Assessing mathematics self-efficacy of diverse students from secondary schools in Auckland: Implications for academic achievement. Issues in Educational Research, 15, 37-68.

[26] Marks, G. N. (2008). Accounting for the gender gaps in student performance in reading and mathematics: Evidence from 31 countries. Oxford Review of Education, 34(1), 89-109.

[27] Marvin, C., \& Mirenda, P. (1993). Home literacy experiences of preschoolers enrolled in Head Start and special education programs. Journal of Early Intervention, 17, 351-367.

[28] McLellan, Ros, Forbes, Karen, \& Li, J. (2021). Investigating EFL teachers' gender-stereotypical beliefs about learners: A mixed-methods study. Cambridge Journal of Education, 51(1), 19-44.

[29] Mills, N., Pajares, F. \& Herron, C. (2007). Self-efficacy of College Intermediate French Students: Relation to Achievement and Motivation. Language Learning, 57(3), 417-442.

[30] Ministry of Education. (1953). Suggestions for problem of what kind of the language should be used in the minority area schools. In He, D. (ed.), Important Education Document From Year 1949-1975 in P.R. China. Haikou: Hainan publisher, 195. 
[31] Ministry of Education. (1956). About the problem of using the minority language in the Mongolian school. In He, D. (ed.), Important Education Document From Year 1949-1975 in P.R. China. Haikou: Hainan publisher, 195.

[32] Ministry of Education. (1962). Announcement on the priority of the minority students to enroll in the high school. In He, D. (ed.), Important Education Document From Year 1949-1975 in P.R. China. Haikou: Hainan publisher, 1114.

[33] Ministry of Education. (1980). Announcement on the minority class in Key high school in Year 1980. In He, D. (ed.), Important Education Document From Year 1949-1975 in P.R. China. Haikou: Hainan publisher, 411-412.

[34] Ministry of Education. (1982). Syllabus for the Chinese language education for whole day school (draft). In He, D. (ed.), Important Education Document From Year 1949-1975 in P.R. China. Haikou: Hainan publisher, 415.

[35] Ministry of Education. (2004). Interim measures for the examination and approval of textbooks for ethnic minorities in Primary and Middle Schools. http://www.moe.gov.cn/srcsite/A09/moe_750/200405/t20040517_77844.html (accessed 02/2/2021).

[36] Ministry of Education. (2005). The implementation Plan of training program for high-level professionals of ethnic minority Origins. http://www.moe.gov.cn/s78/A09/mzs_left/moe_763/tnull_8651.html (accessed 02/2/2021).

[37] Ministry of Education. (2017). Circular on matters related to the morality of compulsory Education and the Rule of Law, Chinese, History and Science Teaching Books in Primary Schools in 2017. http://www.moe.gov.cn/srcsite/A26/moe_714/201707/t20170703_308452.html (accessed 02/2/2021).

[38] National People's Congress. (1995). The education law of the people's Republic of China. http://www.moe.edu.cn/publicfiles/business/htmlfiles/moe/moe_619/200407/1316.html (accessed 28/1/2021).

[39] National Ethnic Affairs Commission. (2017). The plan of ethnic minority languages during the 13th five-year Plan of NEAC. https://www.neac.gov.cn/seac/zcfg/201704/1074196.shtml (accessed 02/2/2021).

[40] Oettingen, G. (1995). Cross-cultural perspectives on self-efficacy beliefs. In A. Bandura (Ed.), Self-efficacy in changing societies. New York, NY: Cambridge University Press, 149-176.

[41] Pajares, K. (2003). Self-efficacy beliefs, motivation, and achievement in writing: A review of the literature. Reading \& Writing Quarterly: Overcoming Learning Difficulties, 19 (2), 139-158.

[42] Pajares, Frank, \& Valiante, Giovanni. (2001). Gender Differences in Writing Motivation and Achievement of Middle School Students: A Function of Gender Orientation?. Contemporary Educational Psychology, 26(3), 366-381.

[43] Raver CC, \& Knitzer, J. (2002). Ready to enter: What research tells policymakers about strategies to promote social and emotional school readiness among three- and four-year-old children. New York: National Center for Children in Poverty, Mailman School of Public Health, Columbia University.

[44] Rimm-Kaufman, S. E., Fan, X., Chiu, Y-J., \& You, W. (2007). The contribution of the Responsive Classroom approach on children's academic achievement: Results from a three-year longitudinal study. Journal of School Psychology, 45, 401-421.

[45] Sakiz, G., Pape, S. J., \& Hoy, A. W. (2012). Does perceived teacher affective support matter for middle school students in mathematics classrooms?. Journal of School Psychology, 50(2), 235-255.

[46] Standing Committee of the National People's Congress. (2000). The Law of National Language and Writing System of Wider Communication. http://www.gov.cn/ziliao/flfg/2005-08/31/content_27920.htm (accessed 02/2/2021).

[47] Soland, J., \& Sandilos, L. E. (2021). English language learners, self-efficacy, and the achievement gap: Understanding the relationship between academic and social-emotional growth. Journal of Education for Students Placed at Risk, 26(1), 20-44.

[48] Smith,J. K., Smith, L. F., Gilmore, A. \& Jameson, M. (2012). Students' self-perception of reading ability, enjoyment of reading and reading achievement. Learning and Individual Differences, 22(2), 202-206.

[49] Teachman, J. D. \& Paasch, K. (1998). The family and educational aspirations. Journal of Marriage and the Family, 60, 704714.

[50] Tong, Y., \& Song, S. (2004). A study on general self-efficacy and subjective well-Being of low SES-College students in a Chinese university. College Student Journal, 38 (4), 637-642.

[51] Van Braak, J. P. (2004). Domains and determinants of university students' self-perceived computer competence. Computers and Education, 43(3), 299-312.

[52] Zhou, Minglang. (2000). Language policy and illiteracy in ethnic minority communities in China. Journal of Multilingual and Multicultural Development, 21 (2): 129-148.

[53] Zins, J., Bloodworth, M., Weissberg, R., \& Walberg, H. (2004). The scientific base linking social and emotional learning to school success. In J. Zins, R. Weissberg, M. Wang, \& H. J. Walberg (eds.), Building academic success on social and emotional learning: What does the research say?. New York: Teachers Press, Columbia University, 1-22.

[54] Li, B., Li, Y. N., \& Hua, C. (2020). Early experience and later multilingual attainments by ethnic minority students in Hong Kong. https://www.tandfonline.com/doi/abs/10.1080/02188791.2020.1820312 (accessed 01/2/2021)

Qiuling Zhang was born in Shizuishan, Ning Xia of China in 1966. She obtained her PH.D. degree in pedagogy from Beijing Normal University, China. She is currently a Professor in the Department of Chinese language Education at School of Chinese language and Literature, Beijing Normal University. Her research interests focus on Chinese curriculum and instruction.

Ningning Zhao was born in Zhuhai, Guangdong Province of China in 1980. She obtained her two PH.D. degrees in University of Gent of Belgium in 2011 and Beijing Normal University of China in 2007. She is currently an associate Professor in the Department of Chinese language Education at School of Chinese language and Literature, Beijing Normal University. Her research interests focus on education assessment, curriculum and instruction. Ningning Zhao is the correspondent author for the present paper.

Xiangying Han was born in Zibo, Shandong Province of China in 1998. She is currently studying at the School of Chinese Language and Literature of Beijing Normal University with a master's degree. Her research interest is education of Chinese subject. 
Li Cheng was born in Zhejiang, China in 1978. She received her PH.D. degree in Psychology from Institute of Psychology, CAS in 2008. She is currently an associate professor in the Faculty of Education, Beijing Normal University, Beijng, China. Her research interests include gifted and talented children and creativity.

Yufei Zheng was born in Changzhi, Shanxi Province of China in 1976. He received his PH.D. degree in education from Beijing Normal University, China in 2010. He is currently an associate professor in the School of education science, Shanxi University, Taiyuan, China. His research interests include curriculum and instruction. 